\title{
"Creating a rule framework for the green revolution in shipping industry" Internal \& territorial waters
}

DOI: https://doi.org/10.25043/19098642.222

Jean-Michel Y. Chatelier ${ }^{1}$

\begin{abstract}
Warning about global warming and the noxious effects of pollution, international institutions already settled drastic reductions in emissions that endanger the atmosphere. These challenges apply as much to the inland navigation industry and the coastal fleet as the ocean ships. Shipping companies are implementing new technologies to go toward the environmental goals. There is obviously a large panel of solutions. None of the solutions is a panacea and the stakeholders must make their choice depending on the type of vessel and the constraints of the area of operation, considering the related regulations to come, if not already in force. As a leading classification society, Bureau Veritas is committed to developing new rules and guidelines to keep shipping safe as it develops these innovative new green projects.
\end{abstract}

Key words: Alternative fuels, new technologies, carbon, risk, rules.

\section{Resumen}

Advirtiendo sobre el calentamiento global y los efectos nocivos de la contaminación, las instituciones internacionales ya establecieron reducciones drásticas en las emisiones que ponen en peligro la atmósfera. Estos desafíos se aplican tanto a la industria de la navegación interior y la flota costera así como a los barcos oceánicos. Las navieras están implementando nuevas tecnologías para avanzar hacia los objetivos ambientales. Obviamente, hay un gran panel de soluciones. Ninguna de las soluciones es una panacea y las partes interesadas deben hacer su elección en función del tipo de embarcación y las limitaciones del área de operación, considerando las regulaciones relacionadas por venir, si es que aún no están vigentes. Como sociedad de clasificación líder, Bureau Veritas se compromete a desarrollar nuevas reglas y pautas para mantener la seguridad del transporte marítimo a medida que desarrolla estos nuevos e innovadores proyectos ecológicos.

Palabras claves: Combustibles alternativos, nuevas tecnologías, carbono, riesgo, reglas.

Date Received: April 15th, 2021 - Fecha de recepción: 15 de abril del 2021

Date Accepted: July 22nd, 2021 - Fecha de aceptación: 22 de julio del 2021 


\section{Introduction}

As international institutions continue to warn about global warming and the noxious effects of pollution, the shipping industry is doing its part by developing new technologies that use green energy. Shipping faces several environmental challenges: the elimination of harmful substances in extinguishing and refrigerating media and anti-fouling paints; the correct disposal of garbage, liquid and ballast products together with appropriate onshore collection; and, of course, the development of a new generation of engines in order to reduce pollutant and greenhouse gas emissions. These challenges apply as much to the inland navigation industry as the deep-sea fleet.

Some countries are already imposing strict regulatory requirements in order to achieve their environmental goals, including reductions in emissions that endanger the atmosphere. At the same time, many shipping companies are implementing new technologies in anticipation of expected future regulation. However, each new energy source and its associated technologies presents new risks that must be managed and mitigated through suitable rules and regulations.

As a leading classification society, Bureau Veritas is committed to developing new rules and guidelines to keep shipping safe as it develops these innovative new green projects. These rules and guidelines must embrace new technology in all the life cycle phases of the ship, from design, to construction, equipment, maintenance and inspection, while always keeping in mind the special needs of the inland navigation fleet.

This paper proposes a review of the possible solutions, matters and technologies that may be implemented on board vessels operated on rivers, internal and domestic waters. The analysis highlights the main related risks to be mitigated as well as the main pros and cons. The study is based on Bureau Veritas Marine \& Offshore's experience thanks to its $R \& D$ and Rules departments as well as approval process of numerous innovative projects.

\section{Environmental challenges}

Beside the political and economic influences, the citizens worldwide expect industries do their part to protect the environment and combat climate change. Transportation is one of the major pillars and shipping is watched closely.

\section{Initial stages}

It is logical that the first step is to avoid emission of pollutant substances in the environment. Additional BV's class notations "Cleanship" - for seagoing ship - or "Cleanvessel" - for inland navigation vessel may be assigned when the Rules requirements for the prevention of pollution by oil, noxious liquid substances in bulk, harmful substances carried in packed form, sewage, garbage and gas emissions, are met. Those requirements cover waste management, oil wastes, wastewaters, garbage, hull antifouling systems, prevention of oil spillage and leakage, refrigerants, fire-extinguishing media and limitation of $\mathrm{NOx}$ and $\mathrm{SOx}$ from thermal engines. Supplementary class notations may be added when treatment plants are fitted on board.

Another step in protecting the environment is to identify all hazardous material that entered in the construction of a vessel and to keep the original inventory updated with modifications all along its lifetime. The class notation "Green Passport" (Bureau Veritas Rule book NR5281) includes the requirement of the 2009 Hong Kong convention (IMO), to ensure safe repairs over the ship's lifetime including the recycling process.

Moreover, the simplest way to avoid emission of exhaust gases in harbour areas is to connect the vessel to the shore installation for energy supply. Indeed, it implies that suitable facilities are available directly from the quay and there is appropriate equipment on board. The class notation "HVSC" covers design, safety, reliability and availability of shipboard electrical and control engineering arrangements to allow operation of services by connection to an external high voltage electrical power supply in port.

https://marine-offshore.bureauveritas.com/nr528-green-passport 
New Goals

IMO a mbitions include ${ }^{2}$ at least $40 \%$ reduction in CO 2 emissions per transport work by 2030 and further aims is reaching $70 \%$ reduction by 2050 , and a global annual GHG emissions reduction of at least $50 \%$ by 2050 , as compared to 2008 . Inland navigation industry is expected to reach the same goals.

Three words pop up in articles and speeches about this topic: "sustainability", "decarbonization" and "resilience". Indeed, the so-called green energy must be sustainable, durable, that means consumed at insignificant rates compared to its supply, with manageable collateral effects and harnessed with little pollution. Decarbonization implies leaving fossil-based energy within the complete chain, well-to-wake, and not solely from ship's tank-towake. Indeed, zero-carbon fuel must be produced from sustainable processes. Resilience is based on the sustainability together with the ability to limit the magnitude of immediate production losses as well as to reconstruct and recover. Energy storage is among the key topics.

There is room for innovation in technology, to make the best of the renewable energy resources and to improve the energy efficiency. Wind power, solar power, hydro-energy, geothermal energy and bioenergy, all possible solutions are analysed at each level of the production chain that start from the raw materials until final consumption.

As each shipping segment is urged to contribute to the reduction of GHGs and to opt for green energy, there is need for the appropriate regulations to deal with the new risks generated by alternative fuels and the related new technology.

With the energy transition a priority, alternative fuels and battery power are increasingly on the agenda for shipowners and operators with the practical challenge of complying with the new regulations. Stakeholders need to evaluate fleet performance and identify sustainable solutions for

2 https://www.imo.org/en/MediaCentre/HotTopics/Pages/CuttingGHG-emissions.aspx existing ships, while deciding how to build future vessels which can deploy alternative fuels or battery systems. Shipowners need to identify how to build a vessel that can sail for the next 25 years or more, regardless of which legislation comes into effect.

While the shipping industry is navigating its way through this period of uncertainty and change, BV's specialists are working hard to prepare the appropriate classification Rules to deal with the new risks generated by alternative fuels and the related new technology.

\section{Regulatory aspect}

In order to support development of new solutions to go toward the environmental goals, appropriate technical regulations must be ready and applicable to ensure the same safety level as the other vessels and to allow the shipowners and managers to obtain the necessary licences to operate. Technologies are used to move forward faster than regulations and the technical challenges become regulatory challenges for most of the marine institutions. The national administrations are urged to provide the shipbuilders with appropriate requirements for design, manufacturing and equipment, notably for vessels operated in internal and domestic waters which are not strictly covered by the international conventions.

As an international classification society Bureau Veritas is committed to partner the shipping industry in development of new technologies and to publish comprehensive rules that embrace all the constructive aspects regarding safety and reliability of the installations. As well, those rules have to define the inspections to be performed once ships are in service in order that appropriate maintenance is carried out to maintain the original safety level.

The following pages aim at taking an objective look at the main alternative fuels and their related technologies, in a simple way, and to summarize the majors risks and obstacles together with the classification rules that may offer a suitable support to the stakeholders in designing, constructing and obtaining suitable licences to operate. 


\section{Possible matters and fuel alternatives}

To meet those environmental objectives, maritime companies are exploring a range of clean fuel alternatives. From increasingly common LNG solutions, via "start-up" fuels such as LPG, methanol and biofuels, to less developed options such as hydrogen and ammonia, everything is on the table.

On the pathways to decarbonization, each alternative fuel option has its own advantages and challenges. They are usually ranged as:

- Carbon fuels: LNG, LPG, Methanol/Ethanol

- Carbon neutral: biofuels/biomethane, synthetic methane SNG, green methanol

- Zero carbon: green hydrogen, green ammonia

\section{Natural gas}

Natural gas is a hydrocarbon mixture, mostly methane $(\mathrm{CH} 4)$ of variable composition, mainly methane for more than 95\%. Natural gas is mainly from fossil origin, but it can be produced from biomass. Liquefied natural gas (LNG) is now a well-known alternative fuel within the shipping industry. Producing almost no sulphur oxide ( $\mathrm{SOx}$ ) or particulate matter emissions, it also boasts low nitrogen oxide (NOx) emissions and GHG (greenhouse gas) emissions between 7 and 22\% depending on engine type. Despite these advantages, ships won't achieve zero CO2 emissions with LNG alone. LNG is still a fossil fuel, and it poses the challenge of methane slip.

LNG is stored at temperature of $-162^{\circ} \mathrm{C}(1 \mathrm{bar})$ or $-130^{\circ} \mathrm{C}$ (10 bars) where the volume reduction is about $1 / 600$ compared to natural gas. Its flash point is $-188^{\circ} \mathrm{C}$.

If compressed at normal temperature (CNG), the pressure is 200 to 250 bars and reduction in volume is about $1 / 250$ compared to natural gas. CNG needs two to three times the volume of LNG (its density is 0.16 at 200 bars).

LNG needs about twice the volume of gasoil for same energy (its density 0.45 at $-162^{\circ} \mathrm{C}$ ).
In the tank, LNG evaporates 0.15 to $0.4 \%$ of its amount per day (boil-off). This gas must be used or released in order to maintain the pressure inside the tank.

The main hazards are:

- Jet fire: the leaked combustible material with high pressure can form a jet flow, if the gas is lit at the leakage split, then the jet fire happens.

- Rapid phase transition: phenomenon in incidents where LNG vaporizes violently upon coming in contact with water. There is no combustion, but a huge amount of energy transferred in the form of heat.

- Cryogenic temperature: conventional steel structure exposed at cryogenic temperature would risk brittle fracture where no apparent plastic deformation takes place before fracture.

\section{Petroleum gas}

Liquefied petroleum gas (LPG) is a flammable mixture of hydrocarbon gases used as fuel in heating appliances and vehicles. It is a mixture of propane $(\mathrm{C} 3 \mathrm{H} 8)$ and butane $(\mathrm{C} 4 \mathrm{H} 10)$.

LPG is prepared by refining petroleum or "wet" natural gas, and is almost entirely derived from fossil fuel sources, being manufactured during the refining of petroleum (crude oil) or extracted from petroleum or natural gas streams as they emerge from the ground.

LPG's boiling temperature, vapour pressure and density are depending on composition. Anyway, the latter is greater than air.

Its energy density per volume unit of $26 \mathrm{MJ} / \mathrm{L}$ is lower than either that of petrol or fuel oil.

As its boiling point is low, LPG evaporates quickly at normal temperatures and pressures and it is usually supplied in pressure vessels. The ratio between the volumes of the vaporized gas and the liquefied gas is typically around 250:1. The lowest LPG flash point is $-104^{\circ} \mathrm{C}$. LPG is heavier than air, unlike natural gas, and thus will flow along floors and tend to settle in low spots. The main 
danger is a possible explosion if the mixture of LPG and air is within the explosive limits and exposed to an ignition source.

Commercially available LPG is currently derived mainly from fossil fuels. Although LPG is considered a clean, energy efficient and portable fuel with an affordable price tag, however burning LPG releases more $\mathrm{CO} 2$ per unit of energy than natural gas.

In the meantime, as new technologies and techniques arise, LPG can be further produced from renewable sources.

Using LPG as a fuel can lower emission to air compared to conventional fuels; GHG, sulphur and NOx depending on the engine.

The infrastructure for distribution and bunkering is already largely available to serve potential marine market demand.

The main safety aspects associated with the use of LPG as fuel include:

- risk of fire and explosion after vaporization of liquid LPG into a gaseous state,

- risk of asphyxiation induced by high concentrations of LPG gas since it displaces the oxygen in the air.

\section{Methanol}

Methanol is an organic chemical compound of the alcohols group of substances with the chemical formula $\mathrm{CH} 3 \mathrm{OH}$. Methanol is a clear, colourless liquid that is soluble in water and is biodegradable. It can be made from a variety of sources, including renewables and it is available around the world.

Methanol has a flashpoint of $12^{\circ} \mathrm{C}$, it is flammable, and it burns with no visible flame. It has the potential to react violently with oxygen.

Using methanol as a fuel in spark-ignition engines can offer an increased thermal efficiency and increased power output due to its high octane ratio
(114) and high heat of vaporization. However, its low energy content means that fuel consumption would be higher than hydrocarbon fuels.

Its combustion produces significantly reduced levels of $\mathrm{CO} 2$ emissions, eliminates sulphur oxide (SOx) emissions and limits particulate matter. However, methanol is also toxic and flammable. Methanol-fuelled ships need to be designed and operated with special care, given the gases' toxic and flammable nature.

Bio-methanol, or green methanol, is methanol produced from biomass or the biodegradable element of waste. Bunkering facilities are still limited.

\section{Biofuels}

Biofuels are a sustainable form of energy derived from the harvesting and processing of different types of biomass, including waste, charcoal, wood, fishery and agricultural products. Burning biofuels can have a net-zero carbon impact on the environment, and reduce emissions of greenhouse gases (GHG) such as methane and ozone.

Liquid biofuels such as biodiesel and bioethanol are the most commonly used type of biofuels for ships. Biogas is naturally produced from the decomposition of biomass, which releases a blend of gases, including methane, which can fuel ships. Synthetic fuels, such as synthetic natural gas (SNG), which are created by reforming biomass feedstock can also be considered biofuels.

While the first-generation biofuels are organic materials grown for fuel production purposes, second-generation biofuels are either the byproducts of other biomaterials (e.g. agricultural residue) or the products of non-arable land intended for use as biofuels, and the thirdgeneration biofuels come from microorganisms such as algae.

Most of biofuels are already compatible with modern ship engines and are a convenient alternative fuel source, likely to benefit from a supply chain with fewer emissions. 
Synthetic methane/substitute natural gas (SNG) and bio-methane are another set of attractive options, as they are compatible with current LNG propulsion technologies. However, making SNG carbon neutral depends on the availability of renewable energy, and production remains costly in the short term.

\section{Hydrogen}

Under normal temperature and pressure, hydrogen is gas with neither odour nor colour. It is the lightest element at the most plentiful in the universe, but which is scarcely in natural condition on Earth.

Hydrogen has the highest energy density, $120 \mathrm{MJ} /$ $\mathrm{kg}$ that is 2.2 times more than natural gas.

Hydrogen gas does not have a flash point as it is already a gas at ambient conditions. It means that cryogenic hydrogen will flash at all temperatures above its boiling point $\left(-252.8^{\circ} \mathrm{C}\right.$ at $\left.1 \mathrm{~atm}\right)$.

It rises very fast up to the upper area and it does not stay in confined zone near the ground.

It is easily flammable due to its wide range of explosivity and its low energy of ignition. The flam is not visible, and it does not provide any heat.

Although hydrogen has a very high mass energy density, the fact that it is a very light gas makes its storage and transportation real challenges. The aim of hydrogen storage technologies is thus to reduce the volume that hydrogen naturally occupies in its thermodynamically stable state under ambient conditions.

Storage can be high pressure (700 bars or more) or liquefaction at $-253^{\circ} \mathrm{C}$, which generate additional risks. Also, the process uses energy that may consume up to one third of the gas energy. Another option would be solid storage, where hydrogen is absorbed by metal hydride or absorbed by porous material (solid with large surface like active charcoal, nanotubes of carbon, nanofibers etc.) but currently with limited capacity of storage.
Intrinsically carbon free, hydrogen produces zero $\mathrm{CO} 2$ emission when sourced renewably, and it is clean fuel solutions for internal combustion engines and fuel cells. While hydrogen has a favourable specific energy (about three times higher than that of fuel oil) its energy density is 4-8 times lower, depending on the hydrogen's state.

Production network is still to be intensified and costs (Capex/Opex) are still high.

\section{Ammonia}

Ammonia is a compound of nitrogen and hydrogen with the formula NH3. It is lighter than air ( 0.86 at boiling point) and it has a very narrow flammability range.

Ammonia has a much lower energy density than traditional fuel oils, weighs twice as much as fuel oil and requires three times the space to contain the same amount of energy (between hydrogen and LNG in terms of storage volume).

It ignites and burns poorly compared to other fuels and combustion could lead to higher NOx emissions.

Ammonia produces zero $\mathrm{CO} 2$ emissions, when sourced renewably, and it can be a clean fuel solution for both internal combustion engines and fuel cells.

There are safety issues associated with ammonia's toxicity and caustic properties, which create a need for careful storage and handling. Ammonia can either be pressurised (10 bars) or kept in cryogenic liquid form close to ambient pressure. It can be liquefied at $-33^{\circ} \mathrm{C}$ and stored at atmospheric pressure for use as a marine fuel.

Toxicity is the main issue, but it is also flammable and corrosive.

Ammonia production levels reach nearly 200 million tons annually but price of green ammonia, produced from renewable energy, remains high.

Summary tables 
Table 1. Alternative fuel properties - Storage characteristics.

\begin{tabular}{|c|c|c|c|c|c|}
\hline & $\begin{array}{c}\text { Mass energy } \\
\text { density LHV } \\
\text { (MJ/kg) }\end{array}$ & $\begin{array}{c}\text { Volumetric } \\
\text { energy density } \\
\text { LHV }\left(\mathbf{G J} / \mathbf{m}^{3}\right)\end{array}$ & $\begin{array}{c}\text { Storage } \\
\text { pressure (bar) }\end{array}$ & $\begin{array}{c}\text { Storage } \\
\text { temperature } \\
\left({ }^{\circ} \mathrm{C}\right)\end{array}$ & $\begin{array}{c}\text { Relative tank } \\
\text { volume (without } \\
\text { insulation) }\end{array}$ \\
\hline $\begin{array}{l}\text { Marine Gasoil } \\
\text { (reference) }\end{array}$ & 42.8 & 36.6 & 1 & 20 & 1 \\
\hline LNG & 50.0 & 23.4 & 1 & -162 & 1.6 \\
\hline LPG & 46.1 & 26 & 17 & 20 & 1.4 \\
\hline Methanol & 19.9 & 15.8 & 1 & 20 & 2.4 \\
\hline Liquefied $\mathbf{H}_{2}$ & 120 & 8.5 & 1 & -253 & 4.3 \\
\hline Compressed $\mathrm{H}_{2}$ & 120 & 7.5 & 700 & 20 & 4.9 \\
\hline Ammonia & 18.6 & 12.7 & $\begin{array}{r}1 \\
10 \\
\end{array}$ & $\begin{array}{r}-34 \\
20\end{array}$ & 2.9 \\
\hline
\end{tabular}

Table 2. Safety issues - Summary .

\begin{tabular}{|c|c|c|c|c|c|}
\hline & Fire / explosion & Pressure & Toxicity & $\begin{array}{c}\text { Corrosivity \& } \\
\text { Materials }\end{array}$ & Cryogeny \\
\hline $\begin{array}{l}\text { Marine Gasoil } \\
\text { (reference) }\end{array}$ & $\mathrm{X}$ & $\mathrm{X}$ & & & $\mathrm{X}$ \\
\hline LNG & $\mathrm{X}$ & $\mathrm{X}$ & & & \\
\hline LPG & $\mathrm{X}$ & & & & $\mathrm{X}$ \\
\hline Methanol & $\mathrm{X}$ & & $\mathrm{X}$ & & \\
\hline Liquefied $\mathrm{H}_{2}$ & $\mathrm{X}$ & $\mathrm{X}$ & & $\mathrm{X}$ & \\
\hline Compressed $\mathrm{H}_{2}$ & $\mathrm{X}$ & & & $\mathrm{X}$ & $\mathrm{X}$ \\
\hline Ammonia & $\mathrm{X}$ & & $\mathrm{X}$ & $\mathrm{X}$ & \\
\hline
\end{tabular}

\section{Technologies}

There are many options for reduction of air pollutants and GHG emissions. Although new fuels and sources of energy are shaping the future, however choosing optimization and energy savings can be a first step. It can start with improvement in energy management and operational conditions, with further optimization in hull forms, propellers and coating. However, many studies have been carried out, giving a panel of combinable solutions which have been already applied with positive results, but they remain behind the challenging path to meet the environment goals.

While carbon neutral or carbon-free fuel production are developing (possibly including carbon capture) the number of possible alternative solutions in the long run is increasing, each of them with pros and cons. The international and national regulations are not yet ready for all technical options, generating shilly-shallying among the maritime and inland navigation industries. Furthermore, regulations usually set the suitable technical arrangements, but they don't provide the constructive dispositions for manufacturing, notably material, components of equipment and tests, and assembling on board.

The classification rules are providing the constructive requirements about each fuel. They refer to the main rule books, NR467 ("Rules for the classification of steel ships") for seagoing ships and NR217 which is applicable to inland navigation vessels. Both are linked to NR216 
which provide the requirements about materials and welding. The requirements for approval of equipment in hull and machinery are given in the Rule book NR266 ("Requirements for Survey of materials and Equipment for the Classification of Ships and Offshore Units", complete with NR544 for pure inland navigation vessels (although the latter may refer to the former as far as necessary). Additionally, the Rule note NR320 settles the certification scheme of materials and equipment for classification.

Moreover, the initial conditions for approval of any system must be maintained once it is in service, especially with regard to the specific hazards inherent to the new fuels and technologies. The classification rules settle the periodical inspections as well as the scope of survey for each part of a ship. The pages hereafter would outline the situation of the main technical options regarding the specificity, the regulations and the classification approach.

\section{Thermal engines}

\section{Natural gas}

LNG is still a fossil fuel, and it poses the challenge of methane slip. Caused by incomplete LNG combustion in the ship engine, methane - a potent greenhouse gas - is emitted into the atmosphere, partly offsetting the $\mathrm{CO} 2$ emissions reduction. This is a key area for technological development, as manufacturers are working to improve the design of engines to limit methane slip.

The one main advantage of LNG today is that it is available in large quantities at attractive prices. Another challenge with LNG has been limited bunkering infrastructure and higher CAPEX. However, thanks to huge investment in global LNG bunkering facilities and favourable OPEX conditions, the price of LNG is falling, making it increasingly competitive with existing fuels. This trend is set to continue as global build-up of LNG bunkering infrastructure progresses. As LNG gains traction as a clean fuel solution, greater numbers of LNG-powered vessels are being built; the global order book lists about $20 \%$ of newbuild orders as LNG-powered.
Although natural gas is relatively new in inland navigation activities, however it is used in shipping industry for nearly 50 years since the first LNG carrier has been operated.

There are three types of engines:

- Spark ignited lean burn engine (Otto cycle)

LNG engines were developed for landbased power industry with requirements on simplicity and good overall performance with low emissions. It runs with low pressure gas supply, 4 to 5 bars. The gas is injected in the air charge to the cylinder where the mixture is compressed and ignited by a spark.

- Diesel ignited dual fuel engine (Combined Ottol Diesel cycle)

Gas engine with dual fuel capability was developed originally for land-based power plants. Development focused on low NOx emissions at high load, then also for variable speed capability. The diesel-ignited LNG engine is the first type used in the marine industry and it is currently the more common type. It runs with low pressure gas supply, 4 to 5 bars. This type of engine is also suitable to work with diesel only.

- High pressure direct injection engine (Diesel cycle) It came to use in the offshore industry where its high fuel flexibility and very high-power density are attractive. There is no requirement for the self-ignition stability. The operating principle ensures that the combustion of the gas fuel is very complete but with higher NOx emissions than other gas engine types. Currently, its use in the marine industry is still limited but promising. The operating principle is based on high pressure gas injection, 300 to 350 bars, the air is compressed, and the gas is injected directly into the cylinder at the end of the compression stage.

The IMO regulations are the SOLAS Convention and the IGF Code ("International Code of Safety for Ships Using Gases or other Low-Flashpoint Fuels”).

The European regulation allows LNG propulsion for inland navigation vessels and the requirements 
are laid down in the standard ES-TRIN (cf. Chap 30 and Annex 8, section 1).

The Classification Rule Note NR529 ("GasFuelled Ships") applies to ships fitted with internal combustion engine using natural gas as fuel. The gas may be stored in gaseous (CNG) or liquid (LNG) state. This Rule book incorporates the text of the IGF Code and provide some additional requirements and interpretations of the Code. The additional service feature "gasfuel" (or "dualfuel") is added to the classification notations. The specific requirements aim at mitigating risks due to particulars of natural gas, covering especially:

- Risk analysis

- Location and separation of spaces: gas process room, machinery spaces containing gas fuelled engines and tank rooms

- Arrangement of entrances and other opening

- Arrangement of gas piping and liquefied gas piping

- Design of machinery spaces. There are two alternative systems:

a) Gas safe machinery spaces: arrangements follow the provisions of IGC Code (International Code for the Construction and Equipment of Ships carrying Liquefied Gases in Bulk), Chapter 16, such that the spaces are considered gas safe under all conditions, normal as well as abnormal conditions i.e. inherently gas safe.

b) ESD protected machinery spaces: arrangements in machinery spaces are such that the space itself acts as the pipe enclosure required by IGC Code, Chapter 16. In the event of abnormal conditions involving gas hazards, emergency shutdown (ESD) of non-safe equipment (ignition sources) and machinery must be automatically executed, and the equipment and machinery in use during these conditions must be certified as safe type.

- Gas supply system in gas machinery spaces (gas safe or ESD)

- Storage tanks used for liquefied gas are designed in accordance with IGC Code, Chapter 4

- Gas fuel bunkering, transfer and distribution systems outside machinery spaces
- Ventilation system (ventilation of hazardous and non-hazardous spaces, gas tank storage room, ESD machinery spaces, process rooms)

- Fire detection and alarm system

- Fire extinction (fire main and water spray, dry chemical powder)

- Electrical systems depending on hazardous areas divided into zones 0,1 and 2 according to risk of explosive gas atmosphere.

- Monitoring of gas tank, gas process and gas engine

- Gas detection (enclosed spaces and open areas)

- Gas compressors (remote emergency stop)

\section{Petroleum gas}

Liquid LPG is supplied to the engine at a pressure of 50 bar. To achieve a full atomization of the liquid LPG when leaving the injection valves nozzles, 600-bar injection pressure is necessary.

The system (ME-LGI, for liquid gas injection) utilizes the fuel booster injection valve (FBIV) that combines hydraulic actuated plunger pump with spring-loaded injection needle valve which opens at given fuel pressure.

Exhaust Gas Recirculation (EGR) or Selective Catalytic Reduction (SCR) system is necessary to fulfil the IMO NOx emission limits.

Regarding safety, the IMO regulation is the IGF Code, although compliance of LPG-fuelled ships should be demonstrated through alternative design. Classification allows assignment of the additional service feature "gasfuel (LPG)", or "dualfuel (LPG)", in either liquid or gaseous state, referring to the note NI647 "LPG-Fuelled Ships". It covers the arrangement, installation, control and monitoring of machinery, equipment and systems using LPG to minimize the risk to the ship, its crew and the environment, mainly:

- Risk assessment

- Fuel containment and fuel piping and protection against mechanical damage, also considering that any released gas is led to a safe location. The provisions of NR529 for material and design of LNG piping systems also apply to LPG. 
- Design / working Pressure

- Arrangement of machinery spaces

- LPG preparation room means any space containing pumps, compressors, heat exchangers and vaporizers for LPG preparation purposes. This room must be located on open deck or where it can withstand the maximum pressure in the worst leakage scenario.

- Regulations for bilge systems and drainage arrangements

- Drip trays

- Venting arrangements

- Prevention of phase changes in LPG supply lines

- Arrangement of the bunkering station

- Secondary enclosure for LPG fuel piping

- Fire safety and explosion prevention

- Ventilation systems serving hazardous spaces

- Electrical installations. The provisions of NR529 also apply to LPG

- Control, monitoring and safety systems

\section{Methanol}

To use methanol safely, additional CAPEX is required for storage and handling. While the CAPEX gap is smaller than for LNG, fuel costs are less favourable when compared with LNG and LPG.

Methanol can be used in spark-ignition engines. It can offer increased thermal efficiency and power output (as compared to gasoline) due to its high octane ratio (114) and high heat of vaporization. However, methanol's low calorific value also means that ships would need to burn greater quantities than hydrocarbon fuels to travel the same distance. Due to formation of acidic products during combustion, the wearing of valves, valve seats, and cylinders might be higher than with hydrocarbon burning. Certain additives may be added to the fuel in order to neutralize these acids.

As an alternative, methanol can be mixed with ordinary fuel. For instance, some current projects on existing vessels are based on adaptation to existing engine with mixture of methanol $(70 \%)$ and diesel (30\%).

The IMO regulation for use of methanol is the interim guideline MSC.1/Circ.1621 pending final text.
Regarding classification, the new Rule book NR670 has been issued. It is in line with the IMO requirements and it provides additional requirements notably about constructive dispositions.

The specific requirements are relating to:

- Cofferdams surrounding fuel tanks

- Ventilation of void spaces

- Bilge system

- Drip trays

- Design of fuel piping

- Fuel distribution (engine components, double walled pipes, segregation)

- Fuel containment system, tank segregation

- Fire detection and extinguishing system, alarms and heat detectors depending on hazardous areas

\section{Biofuels}

Ship managers also need to account for a handful of biofuel-specific technical challenges such as oxidation stability, cold flow properties, and the risk of microbial growth. Also, for certain types of engines, ship managers may need to choose a different lube oil.

For maritime stakeholders who are uncertain about committing to biofuels as a fuel solution, mixed fuels are another possibility. By mixing traditional carbon fuels with biofuels or synthetic fuels, known as "drop-in" fuels, ship owners can take a pragmatic step towards lowering their emissions. Ships can burn mixed fuels without encountering technical, safety or regulatory difficulties, and ship operators can avoid questions of port-by-port biofuel availability. As part of mixed fuels, biofuels can provide a workable entry point into carbon-neutral shipping for shipowners, operators and managers.

The regulations are those applicable to the original matter (diesel, LNG, ...). It is same regarding classification but the type approval certificates covering the engine and other components in contact with the biofuel may need to be reconfirmed when the physical and chemical particulars of the product differ from those of the original approval. 


\section{Hydrogen}

One of the two means for using hydrogen as energy on board is thermal engines. Hydrogen can be injected as a gas in a thermal engine, it may be pure or mixed with diesel (cf. supra). In the latter configuration, $1 \mathrm{~kg}$ of hydrogen may replace 2.5 to 3 litres of diesel. The energy efficiency is slightly less than classic engines. The proportion of hydrogen in the mixture would decrease proportionally the direct emission of $\mathrm{CO} 2$ but it would increase the NOx emission due to higher burning temperature. The hydrogen combustion engine is simply a modified version of the usual internal combustion engine. The main difference is the stronger design of the engine to withstand the higher pressures.

Three main types of hydrogen engines:

- Direct cylinder injection: it is the most sophisticated system with the fuel-air mixture inside the combustion cylinder after the air intake valve is closed.

- Central injection or Carburetted System: fuelair mixture during the intake stroke. It is the simplest method for delivering fuel to hydrogen engine, with the same system as gasoil engine, easy to convert to hydrogen. However, it is more subject to irregular combustion due to pre-ignition and backfire.

- Port injection: it injects fuel directly into the intake manifold at each intake port. Air is injected separately at the beginning of the intake stroke to dilute the hot residual gases and cool any hot spots. The risk of premature ignition is reduced.

Since both the carburetted and port injection methods mix the fuel and air prior to entering in the combustion chamber, these systems limit the maximum theoretical power to approximately $85 \%$ of that of diesel engine.

For direct injection system, the maximum output of the engine can be approximately 15\% higher than that for diesel engine.

The combustion temperature may be very high and a large amount of nitrogen oxides (NOx) may develop. If engine is designed for about twice as much air as required for complete combustion, NOx is reduced to near zero, but the power output is about half that of a similar gasoil engine.

Using hydrogen as fuel requires mitigation of risks. Hydrogen is one of the most flammable products when mixed with air even in small amounts. Ignition can occur due to the oxygen, at a volumetric ratio as low as $4 \%$.

The hazards related to liquefied hydrogen are multiple. Special attention is required due to low ignition energy, wide range of flammability limits, low visibility of flames in case of fire and high flame velocity which may lead to detonation with shockwave. Additionally, low temperature may generate embrittlement compromising the stressed structure's mechanical performance including weld metals. Also, inert gas and constituents of air may come to liquefaction and solidification which may result in an oxygen-enriched atmosphere. As a rule, low temperature hazard implies strict selection of appropriate materials.

In terms of regulation, the IMO resolution MSC.420(97) "interim recommendations for carriage of liquefied hydrogen in bulk" provides guideline for storage.

From classification point of view, the guideline NI547 concerning fuel cells also supplies with requirements concerning containment and use of hydrogen. All pressure vessels, gas pipes, ducting, valves, expansion bellows must be type approved according to the classification rules.

All components in contact with hydrogen should be made of appropriate material, in particular with respect to embrittlement and hydrogen attack phenomena. In the case of compressed gaseous hydrogen, the normal operating temperature range for materials used in hydrogen components should be $-40^{\circ} \mathrm{C}$ to $+85^{\circ} \mathrm{C}$ that must be the gas temperature in normal operating conditions including filling or discharging.

Non-metallic piping carrying hydrogen gas may accumulate electrostatic charge along its exterior surface. Discharges from the external surface of 
those pipes may be enough to ignite any flammable mixture of gas or vapour in the surrounding environment. When used in hazardous locations, measures to eliminate electrostatic discharges are necessary. This may be achieved by specifying pipe material with sufficient conductivity, or by limiting gas flow velocity below values where electrostatic charge might accumulate. Piping that relies on protective system to eliminate electrostatic discharge (grounding wire or braid) should not be used in major hazardous zone.

Inerting should be performed, with inert gas that cannot freeze to form a plug when exposed to cold hydrogen prior to venting to avoid an explosive atmosphere in tanks and gas pipes.

The inner pressure vessel designed for liquid hydrogen must allow to operate with temperature of $-253^{\circ} \mathrm{C}$ (including fill pipes and piping before vaporizer). An inert gas subsystem is needed for various purging operations. Hydrogen equipment should be purged before and after using hydrogen. The inert gas should have a low melting point to avoid freezing and formation of a plug.

\section{Ammonia}

As a zero-carbon fuel when produced from sustainable processes, ammonia has caught the attention of ship owners and operators worldwide. It can be a suitable option for use in ships with modified internal combustion engines. It has several advantages over hydrogen, e.g. it has a greater energy density and it does not need to be stored under compression or at very low temperatures.

It ignites and burns poorly compared to other fuels and combustion could lead to higher $\mathrm{NOx}$ emissions unless controlled either by aftertreatment or by optimising the engine process.

Challenges embrace toxicity, corrosiveness, slow ignition, and NOx emissions. They require a combination of new engine and fuel gas supply system technologies. Further challenges include developing the technology that ensures a safe combustion process and conducting tests to determine the total fuel consumption necessary to achieve stable combustion. Its lower energy density must be considered when designing the ship. The volume and weight of storage required also have a significant impact on the operating range of vessels. The main items are storage space and bunker station, fuel treatment/HP fuel pump room, engine room to be gas-safe, engine injection systems, vent and safety system including vent mast.

Engine manufacturers need to limit nitrogen oxide (NOx) emissions when using ammonia, in line with applicable regulations (i.e. MARPOL Annex VI for seagoing ships). To achieve the goal, engineers resort to proven technologies, such as Exhaust Gas Recirculation (EGR) and Selective Catalytic Reduction (SCR).

There are strong signals that cryogenic storage will be considered safer when analysing the consequences of a potential leak. Low-pressure fuel tank can be managed with established technologies. Combustion tests have already shown that ammonia can be used as a drop-in fuel with diesel (usual proportion 20\%). But ammonia requires extra safety precautions and new materials. Nickle and copper found in seals, gaskets, valves and electrical components would corrode quickly once exposed to ammonia, for example, as would most elastomers.

Using ammonia would need a diesel or dualfuel engine that was built using materials that can handle the corrosive nature of ammonia. Materials aside, an engine very similar to today's diesel or dual fuel engines - ammonia can be used in both - could use small quantities of ammonia as a drop-in fuel, while later engines will be optimised for use of ammonia as a main fuel. Manufacturers are in the process of defining the engine components and modules that would need to be updated on existing engines to enable the use of high proportions of ammonia.

Currently, aspects of using ammonia are not explicitly covered by the existing regulatory framework - notably IMO's International Code of Safety for Ship Using Gases or Other Lowflashpoint Fuels (the IGF Code) and require specific attention. The latter does not cover ammonia in detail, therefore an alternative design approach is required. 
The classification guideline NI671 is being published. It follows the key principles:

- Prevention of leakages to limit the consequences of ammonia toxicity: tank and pipe design, double wall piping

- Detection and management of possible leakage: leakage detection and management through water mist system, ammonia concentration reduction system

- Manage possible spillage

- Control of ammonia outboard discharge

- Prevent corrosion: selection of materials

- Containment system (same approach as IMO IGC/IGF Codes). Tanks other than fully pressurized IMO type $\mathrm{C}$ require boil-off management system

- Classification wants risk mitigation by design:

- Avoid ammonia vapour release to the atmosphere

- Fuel storage based on IGC Code principles

- Materials based on IGC Code principles

- Venting management: several proposals for the safety distances around the vent mast and additional systems are foreseen (e.g. emergency ventilation, ammonia concentration

- reduction system)

- Leakage management: double barrier concept (double wall piping), robust pipe design, dilution through water (various types of systems and layout foreseen) and emergency ventilation maybe required.

There is a general IACS uniform requirement (M57) stating that the area where the ammonia machinery is installed is to be served by a hood with negative ventilation system, so as not to permit any leakage of ammonia from dissipating into other areas in the space.

Fuel cells

Fuel cells is a device which convert chemical energy from hydrogen into electrical energy as direct current. This electrochemical reaction occurs between hydrogen and oxygen from air with efficiency range between 35 and 55\% and it emit only heat and water.
Marine stakeholders have begun at developing fuel cells as a source of alternative propulsion. By using fuel cells, ships can run on electrical power, limiting harmful emissions or particulates.

One kilogram of hydrogen can produce same mechanical energy than 4.5 litres of gasoil in thermal engine.

There are different types of fuel cells, depending on the electrolyte and possible fuels, such as:

- PEMFC: Proton Exchange Membrane Fuel Cell, (or Polymer Electrolyte Membrane). It is compact and runs at $80^{\circ} \mathrm{C}$, also it benefits from technical advance and decrease in price due to its use in car industry. However, it uses only pure hydrogen and platinum is needed. The axis of improvement would increase the temperature (up to $200^{\circ} \mathrm{C}$ ) for better efficiency, while the lifetime could be increased.

- SOFC: Solid Oxide Fuel Cell, ceramic membrane. It uses either hydrogen or natural gas, and it can be used in cogeneration due to running at high temperature $\left(900^{\circ} \mathrm{C}\right)$. However, there is a strong thermal inertia (several hours) and it emits CO2 if natural gas is used. It would need improvement of the lifetime and increase in the number of cycles.

The main advantages of fuel cells compared to thermal engines are:

- High efficiency: between 40 and 50\% (instead of $20 \%$ or $30 \%$ )

- No pollutant emission, no GHG (NOx, Sox, $\mathrm{CO} 2$ )

- Low noise level

- No vibration

- Compact technology

- Modular (number of cells for voltage and surface of cells for intensity)

Methanol and water can be converted into a hydrogen rich gas using a reformer that is a device that contains a catalyst and heat-exchanging surfaces for process heat transfer. Methanol reforming takes place typically at $220-300^{\circ} \mathrm{C}$, it is 
an endothermic process, it needs additional thermal energy to drive the process. Due to the relative low reforming temperature of methanol, it may be an interesting option to use methanol reformer in combination with a HT-PEM fuel cell (High Temperature Polymer Electrolyte Membrane). Using a mixture with $60 \%$ methanol and $40 \%$ water is less flammable than pure methanol.

Using methanol requires design to reduce potential risk of fire and leakage because of methanol's low flash point and toxic properties.

There is no regulation yet providing suitable requirements for fuel cells. In Europe, there is currently a draft in preparation for inland navigation vessels that would enter into force in 2024.

According to the Rule Book NR217 for classification of inland navigation vessels, the type and service notation may be completed by the additional service feature "Hydrogencell" when the vessel complies with the Guideline NI 547 "Fuel Cell Systems Onboard Commercial Ships".

It provides criteria for the arrangements and installation of machinery for propulsion and auxiliary purposes to ensure equivalent level of safety and reliability as conventional system.

To achieve this goal, the functional requirements are based on fail-safe design principles:

- Certification of equipment and materials for use in gas system

- Minimize hazardous areas and equipment installed therein

- Minimize ignition sources in hazardous spaces by design, arrangement and suitable equipment

- Arrangements to ensure pockets of gas cannot accumulate under normal and foreseeable failure conditions.

- Arrangements to sustain or restore operation if essential service becomes inoperative

- Ventilation to protect from oxygen deficiency in case of gas leakage

- Gas fuel storage and bunkering arrangements (leakage and overpressure)
- Gas system, piping, containment and overpressure relief arrangements

- Gas-fuel control engineering arrangement

- Gas detection, alarm and shutdown arrangement

- Protection of compartments from gas storage tank rooms and machinery spaces in case of fire

- Protection against the potential effects of gasfuel explosion

- fire detection, protection and extinction measures appropriate to the hazards

All requirements from the classification Rule books relating to specific fuels such as LNG, hydrogen and methanol, must be met (cf. supra).

The classification guideline includes instructions regarding the operational aspect. The operational crew should receive appropriate training in gasrelated safety, operation and maintenance. The training should be delivered by the manufacturer or the gas provider. The training programme, manual and exercises should be specially designed for each individual vessel and its gas installations.

The system supplier should provide the operator with an operating manual that contains safety information presenting the list of potential hazards and safety instructions. Also, a maintenance manual for the gas supply, fuel cell power and monitoring systems should be available. Gas-related emergency drills should be conducted at regular intervals.

Periodical inspections must be carried out by the classification society once the vessel is in service. It implies that trials and maintenance of gas system are performed in such a way that the level of reliability and safety is maintained.

\section{Batteries}

Electric and hybrid ships are currently among the most important developments in the maritime and inland navigation industries. Batteries are the central part of the electric system which store the energy produced by the generators and release it according to the needs of the vessel. 
Table 3. Alternative fuel properties - Storage characteristics.

\begin{tabular}{|c|c|c|c|c|c|c|}
\hline Type & AFC & DMFC & PEMFC & SOFC & $\begin{array}{c}\text { Molten } \\
\text { carbonate fuel } \\
\text { cell }\end{array}$ & PAFC \\
\hline Name & $\begin{array}{l}\text { Alkaline fuel } \\
\text { cell }\end{array}$ & $\begin{array}{l}\text { Direct } \\
\text { methanol fuel } \\
\text { cell }\end{array}$ & $\begin{array}{l}\text { Proton } \\
\text { exchange } \\
\text { membrane fuel } \\
\text { cell }\end{array}$ & $\begin{array}{l}\text { Solid oxide fuel } \\
\text { cell }\end{array}$ & $\begin{array}{l}\text { Liquid Molten } \\
\text { salt }\end{array}$ & $\begin{array}{l}\text { Phosphoric acid } \\
\text { fuel cell }\end{array}$ \\
\hline Electrolyte & Liquid potash & Solid polymer & Solid polymer & Solid ceramic & 600 to 650 & $\begin{array}{l}\text { Liquid } \\
\text { Phosphoric acid }\end{array}$ \\
\hline $\begin{array}{l}\text { Temperature } \\
\left({ }^{\circ} \mathrm{C}\right)\end{array}$ & 70 & 80 to 130 & 70 to 160 & 600 to 1,000 & 10 to 500 & 160 to 210 \\
\hline Power (kW) & 10 to 100 & 25 to 5 & 0 to 200 & 0 to 200 & 10 to 500 & 100 to 400 \\
\hline Combustible & $\begin{array}{l}\text { Hydrogen } \\
\text { Ammonia }\end{array}$ & Methanol & Hydrogen & $\begin{array}{l}\text { Hydrogen } \\
\text { LNG } \\
\text { Methanol }\end{array}$ & $\begin{array}{l}\text { Hydrogen } \\
\text { LNG } \\
\text { Methanol }\end{array}$ & $\begin{array}{l}\text { Hydrogen } \\
\text { LNG } \\
\text { Methanol }\end{array}$ \\
\hline $\begin{array}{l}\text { Electrical } \\
\text { efficiency } \\
(\%)\end{array}$ & 50 to 70 & 40 & 30 to 45 & 50 to 60 & 40 to 60 & 40 \\
\hline Lifetime (h) & 4,000 to 8,000 & 4,000 & 2,000 to 20,000 & 3,000 to 50,000 & 20,000 to 50,000 & 20,000 to 50,000 \\
\hline Starting time & Minute & Minute & Minute & $>10 \mathrm{~h}$ & $10 \mathrm{~h}$ & 1. to $3 \mathrm{~h}$ \\
\hline
\end{tabular}

Battery system may be the suitable option for small coastal ships and inland vessels using full electric propulsion.

C Rate is the current which described how fast the cell is charging or discharging, e.g. $1 \mathrm{C}$ means the cell can charge/discharge within one hour, $0.5 \mathrm{C}$ means charge/discharge within two hours. It is of importance to specify the $\mathrm{C}$ rate at design stage.

Battery technology is developing fast, especially Li-ion batteries and it is widely used in current projects. The main interest in batteries is reduction of impact on environment and carbon footprints, providing high power in small volume and low weight with optimized energy production, distribution and consumption. On the other hand, energy is required to produce electricity used for battery charging.

One of the challenges is to increase the energy density and to manage the risk of thermal runaway and explosion. Also, batteries contain several heavy metals and toxic chemicals and recycling can be an issue.

The specific risks must be mitigated and there are some additional safety measures such as appropriate ventilation (especially when hazardous areas may be created), protection against water ingress and leakage in battery compartment, protection against electrostatic hazard, gas detections, fire protection and fire-extinguishing system with regard to battery type.

Li-on batteries are preferred for their light weight, high energy density, low rate of self-discharge and low maintenance. Li-ion batteries design and characteristics depend on need for power or energy. They can be designed to meet demands for high energy/ low current/long discharge applications to those operating with very high-power pulse output, where they can match the performance of supercapacitors. However, Li-on batteries need protection, they suffer from ageing and there are additional safety concerns that require a risk analysis. Also, cost is still an issue. Battery management system (BMS) is an electronic device associated with battery pack. It monitors and manages electric and thermal states by controlling the environment. It provides communication between the battery system and other macrosystem controllers, such as a power management system (PMS). 
There is no specific regulation for battery system. However, the IEC standards would be applied (notably EC 62619 and IEC 62620, batteries Lithium-ions). In Europe, the standard ESTRIN 2021 provides the requirements for battery propulsion, especially chapters 10 and 11 .

According to the classification Rules NR467 (seagoing ships) and NR217 (inland navigation vessels), the additional notation "Battery System" may be assigned to ships when batteries are used for propulsion or electric power supply. This additional service feature is mandatory when the ship is relying only on batteries for propulsion or electrical power supply for main sources.

Batteries may be lead-acid type, nickel alkaline type or lithium type. Battery cells and battery packs must be type-approved with prototype tests conforming to a national or international standard. The type approval must cover the battery pack and BMS (battery management system). The Rules book NR320 "Certification Scheme of Materials and Equipment for the Classification of Marine Units" must be applied.

For lithium type batteries, a risk analysis covering battery packs, battery compartment and BMS must be submitted. Failure analysis regarding availability of ship propulsion and energy must be submitted. The fire-extinguishing system must be suitable for the battery type. There are also specific requirements for ventilation when using largevented batteries.

\section{Electrical hybrid}

Hybrid system are based on Diesel-electric system coupled with battery system. Hybrid system can be the easiest way in conversion of existing vessels and to reduce fuel consumption.

There are three main types of electrical hybrid:

- Parallel hybrid concept: the electrical engine is fitted in parallel of the propeller shaft. Either the thermal engine or the electrical engine can be used (or both), depending on the needs (e.g. urban operation, manoeuvre). The electrical engine fitted on the reduction gear is small in size.

- The serial electrical hybrid: the electrical engine is fitted in series of the propeller shaft, avoiding mechanical loss due to reduction gear.

- The electrical concept: the generators feed the electrical engine that ensure propulsion in any case. It provides more space in the engine room and it requires less maintenance.

All types can be associated with batteries.

The additional class notation "Electric Hybrid" may be assigned to ships provided with an Energy Storage System (ESS) used to supply the electric propulsion or the main electrical power distribution system of the ship. The ESS aims at assisting the electric propulsion or the main electrical distribution system with the power demand, or to take over from the main source of electrical power. The ESS is a system based on battery packs, semiconductor converter and transformer.

The additional notation "electric hybrid" is completed with (PM) when the power management mode is available as load smoothing mode, peak shaving mode or enhanced dynamic mode. The notation $(\mathrm{PB})$ is assigned when power backup mode is available and ( $\mathrm{ZE})$ when zero emission mode can be chosen.

All the requirements for assignment and maintenance of those notations are given in the Rule books NR467 (seagoing ships) and NR 217 (inland navigation vessels).

Hybrid design allows multiple solutions where the alternative fuels and technologies can be combined. The regulations and the classification Rules applicable to each part of the complete system may be superimposed to cover the risks generated by each fuel or technology.

\section{Synthesis and conclusion}

There is obviously a large panel of solutions to go toward the environmental goals and to comply with the related regulations to come, if 
not already in force. None of the solutions is a panacea and the stakeholders must make their choice depending on the type of vessel and the constraints of the area of operation.

LNG, despite fossil fuel and methane slip, is suitable as clean transition fuel, a step to the right direction for CO2/GHG reduction with easy switch towards carbon neutral biogas and synthetic methane (SNG).

Methanol is another growing alternative fuel choice with several advantages for limiting environmental footprint. It is technically attractive but not economically viable yet. Next steps would tell. Bio-methanol engines can be adapted from units running on LNG.

Biofuels are one of the only carbon-neutral fuels readily available today and they become steadily more available. Until biofuel production becomes more uniform and common, it will be difficult to achieve competitive costs. They may be a steppingstone on the path to decarbonization, offering an accessible carbon-neutral solution in response to growing social pressure to reduce shipping $\mathrm{CO} 2$ emissions. However, mass-scale production of biofuels is not sustainable, particularly since other industries already use biofuels. This leaves them in much the same position as LPG, a partial solution pending the next stage of the energy transition.

Regarding hydrogen, storage - liquid or compressed - remains a technical challenge that would be expensive to solve in the short term. So, ammonia, which acts as a hydrogen carrier, currently shows greater promise as a zero-carbon fuel for shipping. Indeed, ammonia is one of the most widely used chemicals in the world. Although the safety issues associated with ammonia's toxicity and caustic properties are still challenging, however it is predicted as the most affordable green zero carbon fuel for long haul trades. LPG could be a step to ammonia since the technology may be compatible. Battery-powered and electric-hybrid vessels are an increasingly favoured solution for small ships that travel fixed routes. Fully and partially electric ships such as inland navigation vessels and shortsea ferries are already operating in some areas such as Europe and North America. Manufacturers are presently improving battery management systems and increasing battery life solutions, but safety and reliability need to be addressed. We may expect installation on larger ships in the near future. Electrical hybrid solution may be a valuable investment on existing vessels by saving on fuel, however the expected reduction in consumption depends on the engine load. It would be more significant during manoeuvres, therefore choice for electrical solution must integrate the manoeuvring time among the operations.

In addition to the technical and economic criteria that path the way to the decision, the regulatory aspect is of major importance. Indeed, technology is used to develop faster than the well-established prescriptive regulations can do, meanwhile alternative design methodologies can be used. Bureau Veritas, as a leading classification society, is committed to partner with shipowners, shipyards and designers and to provide the classification rules covering the new technologies and combination of them. To meet such challenging technical goal, a large panel of experienced specialists and engineers are working hand in hand with the main actors in $\mathrm{R} \& \mathrm{D}$ and development of industrial solutions.

In order to help the decision-makers in opting for a solution pending next stage of development in other fuel or technology are completed, the classification Rules are offering the possibility to validate a design for possible future improvement or conversion. An additional notation mentioning "-prepared" may be assigned (e.g. "Ammonia-prepared”).

While many queries come out from the huge number of documents and presentations about the innovative solutions, the set of classification Rules and guidelines aims at providing the answers with regard to the level of safety and reliability that cannot be debatable in any respect.

\section{References}

Supplementary to Bureau Veritas' sources and communication: 
Friederike Dahlke-Wallat, Benjamin Friedhoff and Sophie Martens, "Assessment of technologies in view of zero-emission IWT" (Report No. 2293, October 2020), Eidgenössisches Departement für Umwelt, Verkehr, Energie und Kommunikation - Bundesamt für Verkehr (BAV) Abteilung Sicherheit / Sektion Schifffahrt, Switzerland for DST Development Centre for Ship Technology and Transport Systems, Duisburg, Germany ; part of the overarching study "Financing the energy transition to-wards a zero-emission European IWT sector"

Olivier Ticos and Patrice Domange - Alca Torda Applications, Sept.2020 - "Formation aux notions fondamentales des technologies de l'hydrogène"

VNF, Voies navigables de France, Direction du Développement, 62408 Béthune, France : "Les cahiers techniques de BATELIA" (Bureau d'Assistance Technique et Logistique pour les Industriels et Artisans), including:

CAHIER TECHNIQUE $\mathrm{N}^{\circ} 1$, Propulsion hybride pour bateaux fluviaux - Édition avril 2018

CAHIER TECHNIQUE $\mathrm{N}^{\circ} 2$, Propulsion hydrogène pour bateaux fluviaux - Édition janvier 2020

CAHIER TECHNIQUE N³, Propulsion gaz

pour bateaux fluviaux - Édition janvier 2020 